\title{
Antioxidant, antimicrobial activities and total flavonoid contents of Cirsium bulgaricum $D C$. leaf extracts
}

\author{
Ayca KARASAKAL, A. Şükrü DEMİRCİ, Nazan TOKATLI DEMIROK, Evren CABI
}

\begin{abstract}
In this study, the antioxidant activities of methanol and acetone extracts of Cirsium bulgaricum DC. (Asteraceae) were evaluated by five antioxidant assays, including phosphomolybdate method, cupric ion reducing capacity (CUPRAC), 2,2'-azinobis(3-ethylbenzothiazoline-6sulfonicacid)/persulfate) ABTS/Persulfate, N, N-dimethyl-pphenylenediamine (DMPD) and a $\mathrm{Ce}(\mathrm{IV})$-based reducing capacity (CERAC) methods. The $80 \%$ methanol and acetone extracts showed $0.005-6.16 \pm 0.03 \mathrm{mmol} / \mathrm{g}$ and $0.004-$ $5.02 \pm 0.02$ [(trolox (TR), catechin (CT), epicatechin (EC), rutin (RT), quercetin $(\mathrm{QR})$, naringin $(\mathrm{NG})$ in CUPRAC and ABTS/Persulfate methods, respectively]. According to DMPD methods, inhibition effect were showed $2.3 \% \pm 0.02$ for $80 \%$ methanol and $4.6 \% \pm 0.07$ for acetone. Ascorbic acid equivalent mmol (AA)/g extract in CERAC method was found to be $0.0834 \pm 0.09$ for $80 \%$ methanol and $0.5622 \pm 0.05$ for acetone. Ascorbic acid equivalent $\mu \mathrm{g}$ ascorbic acid (AA) $/ \mathrm{mL}$ extract
\end{abstract}

were found $807.6 \pm 0.07$ for $80 \%$ methanol and $292.4 \pm 0.01$ for acetone in phpsphomolybdate method. In the addition to the antioxidant activity of the extract, the total flavonoid content was measured. Total flavonoid content of $80 \%$ methanol and acetone extracts was found to be 105.5-645 $\pm 0.04 \mu \mathrm{g} / \mathrm{ml}$ quercetin and rutin equivalent. For the determination of antibacterial activities Escherichia coli (E.coli) ATCC 25922, Escherichia coli(E.coli) O157:H7 ATCC 33150, Salmonella Enteritidis(S.Enteritidis) ATCC 13076, Listeria monocytogenes(L.monocytogenes) ATCC 7644, Staphylococcus aureus(S.aureus) ATCC 25923 bacteria were used as test bacteria. Acetone extracts showed antibacterial activity against all of the tested bacteria ranged between $17.00 \pm 1.72-19.88 \pm 1.75 \mathrm{~mm}$ and $80 \%$ methanol extracts showed antibacterial activity against all of the tested bacteria ranged between $11.35 \pm 1.43-14.43 \pm 1.32 \mathrm{~mm}$.

Keywords: Antioxidant Activity, Antimicrobial Activity, Total Flavonoid Contents, Cirsium bulgaricum
Ayca Karasakal

Department of Chemistry, Art and Science Faculty, Namik Kemal University, 59100 Tekirdag - TURKEY

A.Şükrü Demirci

Department of Food Engineering, Agriculture Faculty, Namik Kemal University, 59100 Tekirdag - TURKEY

Nazan Tokatlı Demirok

Department of Nutrition and Dietetics, School of Health, Namik Kemal University, 59100 Tekirdag - TURKEY

Evren Cabi

Department of Biology, Art and Science Faculty, Namik Kemal University, 59100 Tekirdag - TURKEY

\section{Correspondence:}

Ayca Karasakal

Tel: +902822502658

GSM: +90 5338117347

E-mail: aycakarasakal@yahoo.com

\section{INTRODUCTION}

Plants contain a wide variety of free radical scavenging molecules, such as flavonoids, anthocyanins, cartenoids, dietary glutathionine, vitamins and endogenous metabolites and such natural products are rich in antioxidant activities (1-4). Herbs have been used in many domains including medicine, nutrition, flavoring, beverages, dyeing, repellents, fragrances, cosmetics, smoking, and other industrial purposes. Since the prehistoric era, herbs have been the basis for nearly all medicinal therapy until synthetic drugs were developed in the nineteenth century $(5,6)$. The preservative effect of many plant spices and herbs suggests the presence of antioxidative and antimicrobial constituents in their tissues (7). Recently, interest has increased considerably in finding naturally 
occurring antioxidants for use in foods or medicinal materials to replace synthetic antioxidants, which are being restricted due to their carcinogenicity (8). Flavonoids can be used directly to scavenge $\mathrm{O}_{2}^{-}$and $\cdot \mathrm{OH}$ by single electron transfer. The scavenging process can generally be followed by means of electron spin resonance (ESR) $(9,10)$, but the expense of such instruments hinders their use by the average laboratory. The photochemical reduction of riboflavin was first used to determine the dismutation of $\mathrm{O}_{2}^{-}$. by superoxide dismutase (SOD) (11) and has been adapted for analysis of the dismutation of $\mathrm{O}_{2}^{-} \cdot$ by a model compound of superoxide dismutase and other natural compounds (12). Antioxidants are health beneficial compounds that fight reactive oxygen and nitrogen species and free radicals that may eventually give rise to various diseases. Since plant foods are rich in antioxidant vitamins, phenolic and hydroxycinnamic acids, flavonoids, carotenoids, and anthocyanins (13), consumption of vegetables and fruits in the diet is one of the most efficient ways of preventing these diseases. It is important to measure the antioxidant potency of food material and human plasma for food quality estimation and diagnosis and treatment of diseases, respectively. Recent literature states that a single "total antioxidant capacity (TAC)" index for food labelling may not be adequate because of the lack of standard quantitation methods (14), and thus a series of methods have to be employed to assess the antioxidant quality of food. The genus Cirsium Mill. (thistle; köygöçüren) belongs to subtribe Carduinae of the Cardueae tribe, family Compositae (Asteraceae). The members of the genus have been distributed mainly in Eurasia. There are about more than 250 species throughout the world, while in Turkey the genus is represented with 64 species and 76 taxa $(15,16)$. Some species in the genus such as Cirsium arvense (L.) Scop. (Köygöçüren) and $C$. vulgare (Savi) Ten. (yaygın kangal) are considered as weeds in some parts of the world. The genus is also important for ethnobotanical aspect. Certain taxa are used for different purposes in Turkey (Table 1) C. bulgaricum DC. (pomak kangali) is a biennial species and euxine element that grows in open mountain woods, roadsides, and meadow areas with the limited area in Kırklareli province in Turkey $(15,16)$.

No previous literature study reported the antimicrobial activity of the extracts of Cirsium bulgaricum DC. examined in the present study. Therefore, this is the first study which demonstrates the antioxidant and antimicrobial activity of this plant.The aim of this research was to compare the efficiency of ABTS/Persulfate, DPMD, CUPRAC, CERAC and Phosphomolybdate assays to
Table 1. Some Cirsium taxa used for local people in Turkey.

\begin{tabular}{|c|c|c|c|}
\hline Taxon & $\begin{array}{l}\text { Vernacular } \\
\text { name }\end{array}$ & Usage & Reference \\
\hline $\begin{array}{l}\text { Cirsium arvense (L.) } \\
\text { Scop. }\end{array}$ & Köygöçüren & $\begin{array}{l}\text { Stem, root/ } \\
\text { Orexigenic, tonic, } \\
\text { antihemorrhoidal, } \\
\text { cough, bronchitis }\end{array}$ & (36) \\
\hline $\begin{array}{l}\text { C. creticum d'Urv. } \\
\text { subsp. creticum }\end{array}$ & Eşek çalısı & $\begin{array}{l}\text { Mushroom } \\
\text { poisoning }\end{array}$ & $(37,38)$ \\
\hline C. hypoleucum DC. & Vişne kangalı & Diabetes & (39) \\
\hline $\begin{array}{l}\text { C. rhizocephalum } \\
\text { C.A. Mey. subsp. } \\
\text { sinuatum (Boiss.) PH. } \\
\text { Davis \& Parris }\end{array}$ & Medik & $\begin{array}{l}\text { Boiled and drunk } \\
\text { for dyspnea }\end{array}$ & (40) \\
\hline \multirow[t]{2}{*}{$\begin{array}{l}\text { Cirsium vulgare } \\
\text { (Savi) Ten. }\end{array}$} & $\begin{array}{l}\text { Yaygin } \\
\text { Kangal }\end{array}$ & $\begin{array}{l}\text { Areal parts are } \\
\text { used for heating }\end{array}$ & $(41)$ \\
\hline & & $\begin{array}{l}\text { Stems pelled off } \\
\text { and freshly eaten }\end{array}$ & (42) \\
\hline
\end{tabular}

estimate antioxidant activities. On the other hand, the objective of this work was to investigate the effects of solvents on the extraction of total flavonoid contents and antioxidant activities of Cirsium bulgaricum DC.

\section{MATERIAL AND METHODS}

\subsection{Chemicals and Instruments}

All chemicals, solvents, reagents and standards used in the experiments were purchased from Sigma Chemical Co. All chemicals were of analytical grade. All spectrophotometric measurements were made with a pair of matched Hellma quartz cuvettes using a Shimadzu-1601 UV-Vis spectrophotometer.

\subsection{Preparation of plant extracts}

Specimens of C. bulgaricum DC. were collected in July 2013 from Derekoy, Kurklareli and identified using the Cirsium key given in the Flora of Turkey $(17,18)$ and other relavant literature (16). The specimens collected by the authors are deposited in the herbarium of Namık Kemal University (NAKU).

The leaves of Cirsium bulgaricum DC. were collected in July 2013 from Derekoy, Kirklareli and dried under shade to obtain dry sample. The dried samples were powdered in a Willy Mill to 60-mesh size and used for solvent extraction. For extract preparation, $1 \mathrm{~g}$ of dried leaf samples were added $40 \mathrm{ml}$ of $80 \%$ methanol and $100 \%$ acetone and extracts which is prepared with two different extraction techniques were kept in the dark at room temperature in stoppered flasks. The extracts were filtered through Whatman No. 1. 


\subsection{Preparation of solutions}

For the CUPRAC test of TAC, the following solutions were prepared. $\mathrm{CuCl}_{2}$ solution, $20 \mathrm{mM}$, was prepared by dissolving $0.8524 \mathrm{~g} \mathrm{CuCl}_{2} \cdot 2 \mathrm{H}_{2} \mathrm{O}$ in water, and diluted to $250 \mathrm{~mL}$. Ammonium acetate buffer at $\mathrm{pH}=7.0,1.0 \mathrm{M}$, was prepared by dissolving $19.27 \mathrm{~g} \mathrm{NH}_{4} \mathrm{Ac}$ in ethanol and diluted to $250 \mathrm{~mL}$. Neocuproine $(\mathrm{Nc})$ solution, $7.5 \mathrm{mM}$, was prepared daily by dissolving $0.039 \mathrm{~g} \mathrm{Nc}$ in absolute ethanol, and diluting to $25 \mathrm{~mL}$ with ethanol. For the ABTS test of TAC, the chromogenic radical reagent ABTS, at 7.0 $\mathrm{mM}$ concentration, was prepared by dissolving this compound in water and adding $\mathrm{K}_{2} \mathrm{~S}_{2} \mathrm{O}_{8}$ to this solution such that the final persulfate concentration in the mixture is 2.45 $\mathrm{mM}$. The resulting ABTS radical cation solution was left to mature at room temperature in the dark for $12-16 \mathrm{~h}$, and then used for ABTS/Persulfate assay. The reagent solution was diluted with EtOH at a volume ratio of 1:30 prior to use. For the N,N-Dimethyl-p-phenylenediamine (DPMD) method $10 \mathrm{mM} \mathrm{Fe}(\mathrm{III})$ stock solution was prepared: 0.0676 $\mathrm{g}$ of $\mathrm{FeCl}_{3} \cdot 6 \mathrm{H}_{2} \mathrm{O}$ was dissolved in $1.0 \mathrm{~mL}$ of $0.5 \mathrm{M} \mathrm{H}_{2} \mathrm{SO}_{4}$ and diluted to $25 \mathrm{~mL}$ with distilled water. To obtain $1.0 \times$ $10^{-7} \mathrm{M} \mathrm{Fe}(\mathrm{III})$ working solution, this solution was appropriately diluted to $1.0 \times 10^{-4} \mathrm{M}$ intermediary stock solution and then diluted $10^{3}$ times with $10 \mathrm{mM} \mathrm{H}_{2} \mathrm{SO}_{4}$ to avoid hydrolysis. The $\mathrm{pH} 5.7$ buffer solution was prepared by mixing $45.25 \mathrm{~mL}$ of $2.0 \mathrm{M}$ sodium acetate $(\mathrm{NaOAc})$ with $4.75 \mathrm{~mL}$ of $2.0 \mathrm{M}$ acetic acid (HOAc) solution. DMPD solution at $2.4 \times 10^{-2} \mathrm{M}$ concentration was prepared by dissolving $0.125 \mathrm{~g}$ of DMPD in water, followed by the addition of $0.25 \mathrm{~mL}$ of $0.5 \mathrm{M} \mathrm{H}_{2} \mathrm{SO}_{4}$ and final dilution to $25 \mathrm{~mL}$ with distilled water. The $3.0 \% \mathrm{H}_{2} \mathrm{O}_{2}$ solution was prepared by diluting $30 \%$ commercial hydrogen peroxide with water.

The standard solutions at $1.0 \times 10^{-3} \mathrm{M}$ concentration of antioxidant compounds were all prepared in $80 \% \mathrm{MeOH}$, $100 \%$ acetone. All working solutions of antioxidant compounds were freshly prepared.

\subsection{Determination of total flavonoid content}

The total flavonoid contents were measured by a colorimetric assay $(19,20) .100 .0 \mu \mathrm{l}$ aliquot of extracts in 80 $\%$ methanol and acetone were added to a $10 \mathrm{~mL}$ volumetric flask containing $4 \mathrm{~mL}$ of distilled water. At zero time, 0.3 $\mathrm{mL} \mathrm{5 \%}$ sodium nitrite was added to the flask. After $5 \mathrm{~min}$, $0.3 \mathrm{~mL}$ of $10 \%$ aluminium chloride was added. At $6 \mathrm{~min}, 2$ $\mathrm{mL}$ of $1 \mathrm{M}$ sodium hydroxide was added to the mixture. Immediately, the mixture was diluted to volume with the addition of $3.3 \mathrm{~mL}$ distilled water and thoroughly mixed. Absorbance of the mixture, pink in color, was determined at
$510 \mathrm{~nm}$ versus a blank containing all reagents except samples of extracts or fractions. Rutin and quercetin was used as standard for the calibration curve. Rutin and quercetin equivalents were calculated using standard graph of Rutin and quercetin.

\subsection{Modified CUPRAC Assay}

The CUPRAC method is based on the reduction of a cupric neocuproine complex $(\mathrm{Cu}(\mathrm{II})-\mathrm{Nc})$ by antioxidants to the cuprous form $(\mathrm{Cu}(\mathrm{I})-\mathrm{Nc}) .200 \mu \mathrm{L}$ sample was taken from acetone extract and $80 \%$ methanol extract was diluted with methanol and acetone at a ratio of $1: 10.400 \mu \mathrm{L}$ sample was taken from 1:10 diluted $80 \%$ methanol extract. To a test tube were added $0.5 \mathrm{~mL}$ each of $\mathrm{Cu}(\mathrm{II}), 0.5 \mathrm{~mL}$ ethanol, 1 $\mathrm{mL} \mathrm{Nc}$ and $\mathrm{NH}_{4} \mathrm{Ac}$ buffer solutions. Sample or standart solution $(\mathrm{x} \mathrm{mL})$ and ethanol $(1-\mathrm{x}) \mathrm{mL}$ were added to the initial mixture so as to make the final volume: $4 \mathrm{~mL}$. The tubes were stoppered, and after $1 / 2 \mathrm{~h}$, the absorbance at 450 $\mathrm{nm}\left(\mathrm{A}_{450}\right)$ was recorded against water blank (21). The Standard calibration curves of each antioxidant compound was constructed in this manner as absorbance vs. concentration, and the molar absorptivity of the CUPRAC method for each antioxidant was found from the slope of the calibration line concerned.

If a plant infusion (initial volume $=$ Vcup) prepared from (m) grams of dried plant was diluted (r) times prior to analysis and a sample volume of Vs was taken for analysis from the diluted extract and colour development (after addition of reagents) was made in a final volume of $\left(\mathrm{V}_{\mathrm{f}}\right)$ to yield an absorbance of $\left(\mathrm{A}_{\mathrm{f}}\right)$ and antioxidant capacity of the plant was found using the equation:

Capacity (in mmol/g) $=\left(\mathrm{A}_{\mathrm{f}} / \varepsilon\right)\left(\mathrm{V}_{\mathrm{f}} / \mathrm{V}_{\mathrm{S}}\right) \mathrm{r}\left(\mathrm{V}_{\text {cup }} / \mathrm{m}\right)$

\subsection{Determination of $\mathrm{ABTS} /$ persulfate assay}

To $1 \mathrm{~mL}$ of the radical cation solution, $4 \mathrm{~mL}$ of ethanol were added, and the absorbance at $734 \mathrm{~nm}$ was read at the end of the six minute. The procedure was repeated for the unknown plant extract by adding $1 \mathrm{~mL}$ of the radical cation solution to $\mathrm{x} \mathrm{mL}(\mathrm{x}=0.1$ or $0.5 \mathrm{~mL})$ of dilute plant extract (previously diluted with $\mathrm{H}_{2} \mathrm{O}$ at a volume ratio of 1:20) and (4-x) $\mathrm{mL}$ of ethanol, and recording the absorbance (22). The absorbance difference $(\Delta \mathrm{A})$ was found by subtracting the extract absorbance from that of the reagent blank (pure radical solution). Dried plant was diluted (r) times prior to analysis and a sample volume of Vs was taken for analysis from the diluted extract and colour development (after addition of reagents) was made in a final volume of $\left(\mathrm{V}_{\mathrm{f}}\right)$ to yield an absorbance of $\left(\mathrm{A}_{\mathrm{f}}\right)$. 
Antioxidant capacity of the plant was found using the equation:

Capacity (in mmol/g) $=(\Delta \mathrm{A} / \varepsilon)\left(\mathrm{V}_{\mathrm{f}} / \mathrm{V}_{\mathrm{S}}\right) \mathrm{r}\left(\mathrm{V}_{\mathrm{ABTS}} /\right.$ Persulfate $/ \mathrm{m})$

\subsection{Determination of DMPD method}

Extracts were diluted with its solution at a ratio of 1:10. $30 \mu \mathrm{L}$ sample was taken from acetone extract and $300 \mu \mathrm{L}$ sample was taken from $80 \%$ methanol extract. To a test tube were added $0.5 \mathrm{~mL}$ of $\mathrm{FeCl}_{3}, 1 \mathrm{~mL}$ of acetate buffer solution (pH 5.7), $1 \mathrm{~mL}$ of $\mathrm{H}_{2} \mathrm{O}_{2}(3 \%)$, and $\mathrm{x} \mathrm{mL}$ of sample solution, and the volume was completed to $9-\mathrm{x} \mathrm{mL}$ with distilled water. The mixture was shaken after each addition and then allowed to stand on a water bath at $25^{\circ} \mathrm{C}$ for $5 \mathrm{~min}$. After the addition of $4.8 \times 10^{-3} \mathrm{M}(1 \mathrm{~mL})$ DMPD solution (DMPD solution at $2.4 \times 10^{-2} \mathrm{M}$ described in the original method was diluted 5 times with distilled water to get a final absorbance of $\sim 0.9-1.0$ in the absence of scavenger sample solution), the mixture was kept on the water bath for an additional $20 \mathrm{~min}$, and the absorbance in the absence or presence of sample was recorded against distilled water at $514 \mathrm{~nm}$. The decrease in absorbance in the presence of sample linearly correlated with antioxidant concentration over a reasonable range (23). Percentage of inhibition for all of the dilutions was determined by the following equation:

Inhibition $\%=\left(1-\mathrm{A}_{\mathrm{f}} / \mathrm{A}_{0}\right) 100(\%)$

where $A_{f}$ is the absorbance of the non-scavenged radical and $A_{0}$ is the absorbance of the cation after $20 \mathrm{~min}$ of incubation with the antioxidant.

\subsection{Determination of phosphomolybdate method}

Extracts were diluted with its solution at a ratio of 1:10. $300 \mu \mathrm{L}$ sample were taken from acetone and $80 \%$ methanol extract. Total antioxidant activity of the fractions was evaluated by the phosphomolybdate method using AA as a standard. The assay is based on the reduction of Mo (VI)$\mathrm{Mo}(\mathrm{V})$ by the extract and subsequent formation of a green phosphate/Mo (V) complex at acidic $\mathrm{pH}$. An aliquot of 0.3 $\mathrm{mL}$ extract was combined with $3 \mathrm{~mL}$ of reagent solution (0.6 M sulfuric acid, $28 \mathrm{mM}$ sodium phosphate and $4 \mathrm{mM}$ ammonium molybdate). The tubes containing the reaction solution were incubated at $95^{\circ} \mathrm{C}$ for $90 \mathrm{~min}$. After the samples had cooled to room temperature, the absorbance of the solution was measured at $695 \mathrm{~nm}$ against blank using a spectrophotometer. Methanol $(0.3 \mathrm{~mL})$ in the place of extract is used as the blank. Ascorbic acid equivalents were calculated using standard graph of AA.(24).

The experiment was conducted in triplicates and values are expressed as equivalent of ascorbic acid in $\mathrm{mg}$ per $\mathrm{g}$ of extract.

\subsection{Determination of CERAC method}

Extracts were diluted with its solution at a ratio of 1:10. $200 \mu \mathrm{L}$ sample were taken from acetone and $80 \%$ methanol extract The method is based on the oxidation of antioxidants with cerium (IV) sulphate in dilute sulphuric acid at room temperature. The $\mathrm{Ce}(\mathrm{IV})$ reducing capacity of the sample is measured under carefully adjusted conditions of oxidant concentration and $\mathrm{pH}$ such that only antioxidants and not other organic compounds would be oxidized. The spectrophotometric determination of the remaining Ce (IV) was performed after completion of reaction with antioxidants. To a test tube were added $1 \mathrm{~mL}$ of $2 \times 10^{3-} \mathrm{M}$ $\mathrm{Ce}(\mathrm{IV}), \mathrm{x} \mathrm{mL}$ of sample and $(10-\mathrm{x}) \mathrm{mL}$ of water were added (total volume $=10 \mathrm{~mL}$ ) and mixed well. Absorbance against a reagent blank was measured at $320 \mathrm{~nm}$ after 0.5 h.(25).

If a plant infusion (initial volume $=\mathrm{V}_{\mathrm{E}}$ ) prepared from $\mathrm{m}$ grams of dried plant was dilute (r) times prior to analysis and a sample volume of $\mathrm{V}_{\mathrm{S}}$ was taken for analysis from the diluted extract and colour development (after addition of reagent) was made in a final volume of $\left(\mathrm{V}_{\mathrm{f}}\right)$. The absorbance difference $(\Delta \mathrm{A})$ was found by subtracting the extract absorbance from that of the reagent blank and The molar absorptivity of ascorbic acid $(\varepsilon)$ is $12950 \mathrm{~L}^{-1} \mathrm{~cm}^{-1}$, then the ascorbic acid equivalent antioxidant capacity of the plant (in mmol AA per gram of plant, or simply mmol AA/g) was found using the equation:

Capacity $(\mathrm{mmol} / \mathrm{g})=\left[\mathrm{A}_{\mathrm{f}} / \varepsilon\right]\left(\mathrm{V}_{\mathrm{f}} / \mathrm{V}_{\mathrm{S}}\right) \mathrm{r}\left(\mathrm{V}_{\mathrm{E}} / \mathrm{m}\right)$

\subsection{Bacterial Strains}

$80 \%$ methanol and acetone extracts of plant were individually tested against a panel of bacteria, including Escherichia coli ATCC 25922, Escherichia coli O157:H7, Salmonella Enteritidis ATCC 13076, Listeria monocytogenes ATCC 7644, Staphylococcus aureus ATCC 2592. All strains mentioned above were obtained as actively growing cultures from the American Type Culture Collection (ATCC). Stock cultures of E. coli ATCC 25922, E. coli O157:H7, S. Enteritidis ATCC 13076, L. monocytogenes ATCC 7644, S. aureus ATCC 2592 were grown in Nutrient Broth (Acumedia Manufactuers, Inc., Maryland) at $37^{\circ} \mathrm{C}$ for $24 \mathrm{~h}$ and suspensions were adjusted to $0.5 \mathrm{McF}$ arland standard turbidity (corresponding to $10^{7}$ $10^{8} \mathrm{cfu} / \mathrm{ml}$ for bacteria, depending on genera).

\subsection{Disc diffusion assay}

Antimicrobial activity of methanol and acetone extracts of Cirsium bulgaricum DC. plant was investigated respectively.The agar disc diffusion method was employed 
for the determination of antimicrobial activities of the extracts in question (29). Briefly, a suspension of the tested microorganism $\left(0.1 \mathrm{~mL}\right.$ of $10^{8}$ cells per $\left.\mathrm{ml}\right)$ was spread on the solid media plates. Filter paper discs $(6 \mathrm{~mm}$ in diameter) were impregnated with $20 \mu \mathrm{L}$ of the extracts and methanol (as negative control) and placed on the inoculated plates. After staying at $4^{\circ} \mathrm{C}(2 \mathrm{~h})$, all petri dishes were incubated at $37^{\circ} \mathrm{C}(24 \mathrm{~h})$, except L. monocytogenes that was incubated during $48 \mathrm{~h}$. The diameters of the inhibition zones were measured in millimetres. Tests were carried out in triplicate. Values are presented as means $\pm \mathrm{SD}$ of three paralel measurements.

\subsection{Determination of minumum inhibitory concentration (MIC)}

Bacterial strains sensitive to the plant extracts in disc diffusion assay were studied for their minimal inhibition concentration (MIC) values using micro-well dilution assay method (26). MICs were defined as the lowest concetrations of the antimicrobial agents that inhibited visible growth of the microorganism. For the determination of antibacterial activities E.coli ATCC 25922, E.coli O157:H7, S.Enteritidis ATCC 13076, L.monocytogenes ATCC 7644, S.aureus ATCC 25923 bacteria were used as test bacteria.

The inocula of the microbial strains were prepared from 12 $\mathrm{h}$ broth cultures and suspensions were adjusted to 0.5 McFarland standard turbidity. The extracts of plants dissolved in $10 \%$ DMSO were first diluted to the highest concentration $(1000 \mu \mathrm{g} / \mathrm{mL})$ to be tested, and then serial twofold dilutions were made in a concentration range of 7.8 to $1000 \mu \mathrm{g} / \mathrm{mL}$ in $10 \mathrm{~mL}$ sterile test tubes containing Nutrient broth.

The 96-well plates were prepared by dispensing $95 \mu \mathrm{L}$ of the cultures media and $5 \mu \mathrm{L}$ of the inoculum into each well. A $100 \mu \mathrm{L}$ aliquot from the stock solutions of extracts initially prepared at the concentration of $1000 \mu \mathrm{g} / \mathrm{mL}$ was added into the first wells. Then, $100 \mu \mathrm{L}$ from their serial dilutions was transferred into seven consecutive wells. The last well containing $195 \mu \mathrm{L}$ of nutrient broth without compound and $5 \mu \mathrm{L}$ of the inoculum on each strip was used as the negative control. The fnal volume in each well was $200 \mu \mathrm{L}$. contents of each well were mixed on plate shaker at $300 \mathrm{rpm}$ for $20 \mathrm{~s}$ and then incubated for $24 \mathrm{~h}$ at $37^{\circ} \mathrm{C}$.

Microbial growth was determined by the presence of a white pellet on the well bottom and confirmed by plating 5 $\mu \mathrm{L}$ samples from clear wells on Nutrient Agar medium. The MIC value was defined as the lowest concentration of the extract required for inhibiting the growth of each
Table 2. Analysis results of antioxidants tested with CUPRAC and ABTS methods $(n=3)$

\begin{tabular}{ccccc}
\hline & \multicolumn{2}{c}{$80 \%$ Methanol } & \multicolumn{2}{c}{ Aceton } \\
$\begin{array}{c}\text { Antioxidant } \\
(\mathrm{mmol} / \mathrm{g})\end{array}$ & CUPRAC & $\begin{array}{c}\text { ABTS/ } \\
\text { persulphate }\end{array}$ & CUPRAC & $\begin{array}{c}\text { ABTS/ } \\
\text { persulphate }\end{array}$ \\
\hline TR & $0.18 \pm 0.02$ & $0.14 \pm 0.03$ & $0.02 \pm 0.09$ & $0.01 \pm 0.02$ \\
CT & $0.05 \pm 0.07$ & $0.03 \pm 0.05$ & $0.007 \pm 0.03$ & $0.005 \pm 0.02$ \\
EC & $0.04 \pm 0.09$ & $0.05 \pm 0.08$ & $0.006 \pm 0.06$ & $0.007 \pm 0.07$ \\
RT & $0.06 \pm 0.05$ & $0.07 \pm 0.01$ & $0.009 \pm 0.01$ & $0.01 \pm 0.05$ \\
QR & $0.04 \pm 0.05$ & $0.03 \pm 0.04$ & $0.005 \pm 0.08$ & $0.004 \pm 0.04$ \\
NG & $6.16 \pm 0.01$ & $5.02 \pm 0.07$ & $0.84 \pm 0.07$ & $0.73 \pm 0.08$ \\
\hline a Values are expressed as mean \pm standard deviation(n=3) \\
bTR: Trolox, CT: Catechin, EC: Epicatechin, RT: Rutin, QR: Quercetin, NG: \\
Narengin
\end{tabular}

microorganism. All tests were repeated two times.

\section{RESULTS AND DISCUSSION}

In this study, it is aimed to evaluate the effect of solvent on the antioxidant behavior of phenolic compounds. The TAC measurements in different solvent media of other ET-based assays (i.e., ABTS/persulfate, DMPD, CERAC, Phosphomolybdate method) were compared to those of the CUPRAC assay. Methanol $80 \%$ and acetone $100 \%$ solvent media were chosen as variable solvent environments. The antioxidant compounds of different representative classes used in this work are trolox, catechin, epicatechin, rutin, quercetin naringenin and Vitamin C

\subsection{CUPRAC and ABTS Persulfate method}

The CUPRAC method of total antioxidant capacity (TAC) assay uses bis(2,9-dimethyl-1,10-phenanthroline: neocuproine) $\mathrm{Cu}(\mathrm{II})$ chelate cation as the chromogenic oxidant, which is reduced in the presence of antioxidants to the cuprous neocuproine chelate $[\mathrm{Cu}(\mathrm{I})-\mathrm{Nc}]$ showing maximum light absorption at $450 \mathrm{~nm}$. Colour development in the CUPRAC method is based on the following reaction: (26).

$n \mathrm{Cu}(\mathrm{Nc})_{2}{ }^{+2}+n$-e reductant $\leftrightarrow n \mathrm{Cu}(\mathrm{Nc})_{2}{ }^{+}$

$+n$-e oxidized product $+n \mathrm{H}^{+}$

Antioxidants show some variation with solvent polarity. The various antioxidant compounds found with ET-based CUPRAC, ABTS/persulfate are shown in Table 2. In the CUPRAC assay results, The CUPRAC and ABTS/ Persulfate values of TR, CAT, EC, RT, QR and NG were higher in $\mathrm{MeOH} 80 \%$ than in pure acetone (Table 2), probably due to facilitated e-transfer in ionizing solvents 
Table 3. Inhibition effect of DMPD Method

\begin{tabular}{lc}
\hline & Inhibition effect (\%) \\
\hline MeOH \%80 & $2.3 \pm 0.02$ \\
Acetone & $4.6 \pm 0.07$ \\
\hline
\end{tabular}

${ }^{a}$ Values are expressed as mean \pm standard deviation( $(\mathrm{n}=3$ )

capable of anion (phenolate) solvation, because $\mathrm{MeOH}$ is the alcohol that best supports ionization. $\mathrm{TAC}_{\mathrm{ABTS}}$ ' Persulfate values were closer $\mathrm{TAC}_{\text {CUPRAC }}$ values.

\subsection{DMPD method}

The principle of the assay is that at an acidic $\mathrm{pH}$ and in the presence of a suitable oxidant solution DMPD can form a stable and colored radical cation $\left(\mathrm{DMPD}^{+}\right)$. Antioxidant compounds which are able to transfer a hydrogen atom to $\mathrm{DMPD}^{+}$quench the color and produce a decoloration of the solution which is proportional to their amount.

DMPD (uncoloured) + oxidant $\left(\mathrm{Fe}^{+3}\right)+\mathrm{H}^{+} \rightarrow \mathrm{DMPD}^{++}$(purple) $\mathrm{DMPD}^{+}$(purple) $+\mathrm{AOH} \rightarrow \mathrm{DMPD}^{+}$(uncoloured) $+\mathrm{AO}$

the absorbance at $514 \mathrm{~nm}$ as percentage of the absorbance of the uninhibited radical cation solution (blank) according to the equation:

inhibition of $\mathrm{A}_{514}(\%)=\left(1-\mathrm{A}_{\mathrm{f}} / \mathrm{A}_{0}\right) \times 100$, where: $\mathrm{A}_{0}$ is the absorbance of uninhibited radical cation and $A_{f}$ is the absorbance measured $20 \mathrm{~min}$ after the addition of antioxidant samples. The results of DMPD method is shown in Table 3. In the DMPD assay results, Inhibition effects were higher in acetone than in $80 \%$ methanol solution (23-27).

\subsection{CERAC and Phosphomolybdate method}

For CERAC method, the equation for the calibration line of ascorbic acid in the ascorbic acid concentration range $1.5 \times$ $10^{5-}$ to $7.5 \times 10^{4-} \mathrm{M}$ was: $\mathrm{A}_{320}=1.295 \times 10^{4}$ Casc. -0.9648 , $\left(\mathrm{R}^{2}=0.99\right)$ yielding a molar absorptivity of $1.295 \times 10^{4} \mathrm{~L}$ $\mathrm{mol}^{-1} \mathrm{~cm}^{-1}$ for ascorbic acid. Antioxidants were quantified indirectly through their ability to reduce a fixed initial concentration of $\mathrm{Ce}(\mathrm{IV})$. For Phosphomolybdate method, the equation for the calibration line of ascorbic acid in the ascorbic acid concentration range 25 to $400 \mu \mathrm{g} / \mathrm{ml}$ was: $\mathrm{A}_{695}=3.8 \times 10^{2-}$ Casc. $-0.0171,\left(\mathrm{R}^{2}=0.99\right)$ yielding a molar absorptivity of $3.8 \times 10^{2-} \mathrm{L} \mathrm{mol}^{-1} \mathrm{~cm}^{-1}$ for ascorbic acid. phosphomolybdate method was based on the reduction of Mo (VI) to Mo (V) by the antioxidant compound and the formation of a green phosphate/Mo (V) complex with a maximal absorption at $695 \mathrm{~nm}$. The phosphomolybdate
Table 4. CERAC and Phosphomolybdate analysis results

\begin{tabular}{lcc}
\hline & $\begin{array}{c}\text { Cerac Method } \\
(\mathrm{mmol} \mathrm{AA} / \mathrm{g})\end{array}$ & $\begin{array}{c}\text { Fosfomolibden Method } \\
(\mu \mathrm{g} \mathrm{AA} / \mathrm{ml})\end{array}$ \\
\hline MeOH \%80 & $0.0834 \pm 0.09$ & $807.6 \pm 0.07$ \\
Acetone & $0.5622 \pm 0.05$ & $292.4 \pm 0.01$ \\
\hline
\end{tabular}

${ }^{a}$ Values are expressed as mean \pm standard deviation $(n=3)$

method is a quantitative since the total antioxidant activity is expressed as AA (ascorbic acid) equivalent. In the CERAC assay results, AA were higher in acetone than in $80 \%$ methanol solution and In the Phosphomolybdate method assay results, AA were higher in methanol $80 \%$ than in acetone solution. Analysis results are shown in Table 4 (24-25).

\subsection{Total flavonoid content}

Flavonoids are the most common and widely distributed group of plant phenolic compounds, characterized by a benzo- $\gamma$-pyrone structure. It is ubiquitous in fruits and vegetables. Total flavonoid contents can be determined in the sample extracts / fractions by reaction with sodium nitrite, followed by the development of coloured flavonoidaluminum complex formation using aluminum chloride in alkaline condition which can be monitored spectrophotometrically at maximum wavelength of $510 \mathrm{~nm}$. The total flavonoid content was expressed as rutin, quercetin equivalents (RE) in microgram per mililiter of extracts (28). Flavonoids as one of the most diverse and widespread group of natural compounds are probably the most important natural phenols. These compounds possess a broad spectrum of chemical and biological activities including radical scavenging properties. The flavonoid contents of Cirsium bulgaricum DC. were calculated using the standard plots of quercetin and rutin, respectively $\mathrm{y}=0.0011 \mathrm{x}-0.018, \mathrm{R}^{2}=0.997$ and $\mathrm{y}=0.0001 \mathrm{x}$ $+0.049, \mathrm{R}^{2}=0.998$. Total flavonoid contents are shown in Table 5.

\subsection{Statistical analysis}

The data's are expressed as mean \pm standard deviation (SD) from three parallel measurements. The Pearson correlation analysis was performed between antioxidant activity and total flavonoids. There were strong positive significant correlations between CUPRAC and contents of flavonoids, ABTS/Persulfate and contents of flavonoids. $(\mathrm{p}<0.01)$. Pearson's correlation coefficient was calculated using Microsoft Excel 2010. 
Table 5. Total flavonoid contents of Cirsium bulgaricum leaf extracts $(n=3)$

\begin{tabular}{lcc}
\hline & $\mathrm{QR}(\mu \mathrm{g} / \mathrm{mL})$ & $\mathrm{RT}(\mu \mathrm{g} / \mathrm{mL})$ \\
\hline MeOH \%80 & $119.5 \pm 0.03$ & $645 \pm 0.004$ \\
Acetone & $105.5 \pm 0.1$ & $490 \pm 0.08$ \\
\hline
\end{tabular}

${ }^{a}$ Values are expressed as mean \pm standard deviation $(\mathrm{n}=3)$

\subsection{Antimicrobial effect}

Antibacterial activities of the methanol and acetone extracts of Cirsium bulgaricum DC. plant evaluated here were determined by the application of agar disc diffusion and MIC tests against a panel of pathogenic bacteria. The results are given in Table 6. As expected, the negative control treatment (absolute methanol) had no inhibitory effect on any of the test bacteria. As summarized in Table 6, methanol and acetone extracts of $C$. bulgaricum showed antibacterial activitiy against all pathogenic bacteria tested, particularly against gram-positive bacteria.

In general, the acetone extract possessed higher antibacterial activity than methanol extract of $C$. bulgaricum with diameter of inhibition zones ranging from $12.70-17.60 \mathrm{~mm}$, while it was $11.60-14.43 \mathrm{~mm}$ for the methanol $80 \%$ extract. The results from the disc diffusion method, followed by measurement of minimum inhibitory concentration (MIC), indicated that L.monocytogenes ATCC 7644 was the most sensitive microorganisms tested, showing the highest inhibition zones (14.43 $\mathrm{mm}$ for methanol extract and 19.88 $\mathrm{mm}$ for acetone extracts) and the lowest MIC values (250 $\mu \mathrm{g} / \mathrm{mL}$ for both extracts). Other sensitive microorganism was S.aureus ATCC 25923 of which inhibition zone and MIC values are 13.55 (methanol), 18.99 (acetone) and $250 \mu \mathrm{g} / \mathrm{mL}$ respectively. The methanol extract of the plant showed weak antibacterial activity against S.Enteritidis ATCC 13076 and E.coli $\mathrm{O} 157: \mathrm{H} 7$ in both disc diffusion and MIC tests.

The resistance of these Gram negative bacteria could be due to the complexity of their double layer cell membrane in comparision with the single membrane of Gram positive bacteria (31). In this regard, the extracts of the plant was showed its best antibacterial activity in both disc diffusion and MIC tests on gram positive bacteria (L.monocytogenes ATCC 7644 and S.aureus ATCC 25923) tested. However, its inhibitory effect on Gram negative bacteria was also considerable. Overall the extracts of plant displayed moderate activity against the test bacteria.

Nazaruka was examined Antioxidant activity of Cirsium (Asteraceae): C. arvense (L.) Scop., C. oleraceum (L.) Scop., C. palustre (L.) Scop., C. rivulare (Jacq.).The plants were extracted with
Table 6. Antibacterial activity against pathogenic bacteria of the methanol and acetone extracts of Cirsium bulgaricum ${ }^{\text {a }}(\mathrm{n}=3)$

\begin{tabular}{|c|c|c|c|c|c|}
\hline Microorganisms & $\begin{array}{c}\mathrm{MeOH} \\
\% 80\end{array}$ & & Acetone & & $\begin{array}{l}\text { Negative } \\
\text { Control }\end{array}$ \\
\hline & $\begin{array}{c}\text { Disc } \\
\text { diffusion }^{\mathrm{b}}\end{array}$ & $\mathrm{MIC}^{\mathrm{c}}$ & $\begin{array}{c}\text { Disc } \\
\text { diffusion }\end{array}$ & MIC & Methanol \\
\hline $\begin{array}{l}\text { E.coli ATCC } \\
25922\end{array}$ & $12.0 \pm 1.05$ & 500 & $17.65 \pm 1.89$ & 250 & NA \\
\hline E.coli $\mathrm{O} 157: \mathrm{H} 7$ & $11.6 \pm 1.00$ & 500 & $17.00 \pm 1.72$ & 500 & NA \\
\hline $\begin{array}{l}\text { S.enteritidis } \\
\text { ATCC } 13076\end{array}$ & $11.35 \pm 1.43$ & 500 & $17.60 \pm 1.46$ & 500 & NA \\
\hline $\begin{array}{l}\text { L.monocytogenes } \\
\text { ATCC } 7644\end{array}$ & $14.43 \pm 1.32$ & 250 & $19.88 \pm 1.75$ & 250 & NA \\
\hline $\begin{array}{l}\text { S.aureus ATCC } \\
25923\end{array}$ & $13.55 \pm 1.42$ & 250 & $18.95 \pm 1.44$ & 250 & NA \\
\hline
\end{tabular}

${ }^{a}$ Results are means of three different experiments (Mean \pm SD)

${ }^{b}$ Diameter of inhibition zone including disc diameter of $6 \mathrm{~mm}$.

${ }^{\mathrm{c}} \mathrm{MIC}$, minimum inhibitory concentration (as $\mu \mathrm{g} / \mathrm{mL}$ )

NA: Not active

$\mathrm{MeOH}, \mathrm{CHCl}_{3}, \mathrm{Et}_{2} \mathrm{O}, \mathrm{EtOAc}$ and $\mathrm{BuOH}$ (32). Nazaruka et $a l$. were investigated crude aqueous extracts from leaves of Cirsium arvense, C. oleraceum, C. palustre, C. rivulare and C. vulgare. Total phenolic content, analysed by using FolinCiocalteau's method, ranged between 54 and $96 \mathrm{mg} \mathrm{g}^{-1}$, was expressed as milligrams of gallic acid per gram of dry extract. Phenolic acids were identified by HPLC method. Antimicrobial activity of those extracts was examined. The total antioxidant activity indicated by radical cation 2,2' -azini-di-(3-ethylbenzthiazoline sulphonate) ABTS.+ expressed as total antioxidant status (TAS) ranged from 2.31 to $2.78 \mathrm{mM} \mathrm{L}^{-1}$ (33). Yin et al. were investigated the antioxidant, antidiabetic activities and phenolic and flavonoid contents of methanol $(\mathrm{MeOH})$ and water extracts from roots of Cirsium japonicum in vitro by the DPPH method, the aluminum chloride colorimetric method, Hydroxyl radical scavenging activity assay, reducing power assay, ferrous ions chelating activity assay, $\alpha$-glucosidase inhibitory assay and Folin-Ciocalteau's method (34). In Cirsium species, presence of flavonoids (luteolin-7glucoside, -7-glucuronide, cirsiliol, hispudilin, cirsitakaoiside, cirsitakaogenin etc.), triterpenes, acyclic diterpenes ( $\alpha$-tocopherol, trans- phytol), polyolefins, fatty acids (linoleic, linolenic, palmitic, and stearic acids) and some widespread acetylenes have been reported (35).

\section{CONCLUSION}

This study was designed for a detailed investigation of the total flavonoid content profile, antioxidant activity and antimicrobial activity of Cirsium bulgaricum DC. leaves 
growing in Turkey. Five different methods were applied to the test materials in antioxidant activity analysis. The results revealed that each of the methanol $80 \%$ and acetone $100 \%$ extract prepared from these leaves have antioxidant activity and antimicrobial activity. In conclusion, the results obtained from this work demonstrated that the antioxidant behaviour of phenolic compounds show variations based on solvent type and polarity, reaction mechanism, solubility parameters as well as on an essential structural property, i.e., electron-transfer capability According to results , Cirsium bulgaricum DC. leaves have good antioxidant, antimicrobial activity and total flavonoid contents.

\section{Cirsium bulgaricum yaprak ekstresinin antioksidan, antimikrobiyal etkinliği ve toplam flavonoid içeriği}

\section{ÖZET}

Bu çalışmada Cirsium bulgaricum DC. bitkisinin metanol ve aseton ekstraktları dört farklı antioksidan aktivite tayin yöntemi (CUPRAC, DMPD , CERAC ve Fosfomolibden yöntemi) ile incelendi. Cuprac ve ABTS/Persülfat metoduna göre $80 \%$ metanol ve aseton ekstraktları sirasiyla 0.005 $6.16 \pm 0.03 \mathrm{mmol} / \mathrm{g}$ ve $0.004-5.02 \pm 0.02$ aralıklarında $\mathrm{mmol}$ (TR, CT, EC, RT, QR, NG eşdeğeri olarak) /g bulundu. DMPD yöntemine göre $80 \%$ metanol ekstraktı için inhibisyon etkisi $2.3 \% \pm 0.02$ ve aseton için $4.6 \% \pm 0.07$ bulundu. CERAC yöntemine göre, $80 \%$ metanol ekstraktı için $0.0834 \pm 0.09$ $\mathrm{mmol} \mathrm{AA} / \mathrm{g}$, aseton ekstraktı için de $0.5622 \pm 0.05 \mathrm{mmol} \mathrm{AA} / \mathrm{g}$ bulundu. Fosfomolibden yöntemine göre, $80 \%$ metanol ekstraktı için $807.6 \pm 0.07 \mathrm{mmol} \mathrm{AA} / \mathrm{g}$, aseton ekstraktı için de $292.4 \pm 0.01 \mu \mathrm{g}(\mathrm{AA}) / \mathrm{ml}$ bulundu. Total flavonoid içerikleri $80 \%$ metanol ve aseton ekstaktları için $105.5-645 \pm 0.04 \mu \mathrm{g} / \mathrm{ml}$ aralığında quercetin ve rutin eşdeğeri olarak bulundu. Antibakterial etkinin belirlenmesinde test bakterileri olarak Escherichia coli (E.coli) ATCC 25922, Escherichia coli(E. coli) O157:H7, Salmonella Enteritidis(S.Enteritidis) ATCC 13076, Listeria monocytogenes(L.monocytogenes) ATCC 7644, Staphylococcus aureus (S.aureus) ATCC 25923 kullanıld1. Aseton ekstraktları için $17.00 \pm 1.72-19.88 \pm 1.75$ $\mathrm{mm}$ ve $80 \%$ metanol ekstraktları için $11.35 \pm 1.43-14.43 \pm 1.32$ mm aralıklarında test edilen bakterilere karşı antimikrobiyal etki gözlendi.

Anahtar sözcükler: Antioksidan Etki, Antimikrobiyal Etki, Toplam Flavanoid İçeriği, Cirsium bulgaricum

\section{REFERENCES}

1. Larson RA. The antioxidants of higher plants. Photochem 1988; 4 : 969-978.

2. Hertog MGL, Hollman PCH, Katan MB. Content of potentially anticarcinogenic flavonoids of 28 vegetables and 9 fruits commonly consumed in the Nederlands. J Agric Food Chem 1992; $40: 2379-83$.

3. Cao G, Sofic E, Prior RL. Antioxidant capacity of tea and common vegetables. J Agric Food Chem 1996; 44 :34263431.

4. Kivits GAA, Vam der Sman FJP, Tijburg LBM. Analysis of catechin from green and black tea in humans: a specific and sensitive colorimetric assay of total catechins in biological fluids. Int J Food Sci Nutr 1997; 48 : 387-92.

5. Dahanukar SA, Kulkarni RA, Rege NN. Pharmacology of medicinal plants and natural products. Indian $\mathrm{J}$ Pharmacol 2000; $32: 81-118$.

6. Exarchou V, Nenadis N, Tsimidou M, Gerothanassis IP, Troganis A, Boskou D. Antioxidant activities and phenolic composition of extracts from Greek oregano, Greek sage and summer savory. J Agric Food Chem 2002; 50 : 5294-5299.

7. Hirasa K, Takemasa M. Spice science and technology. New York: Marcel Dekker, 1998.

8. Velioglu YS, Mazza G, Gao L, Oomah BD. Antioxidant activity and total phenolics in selected fruits, vegetables, and grain products. J Agric Food Chem 1998; 46 : 4113-7.

9. Chen YT, Li XJ, Zao BL, Zheng RL, Xin WJ. ESR study of the scavenging effect of natural products of rutin etc superoxide and hydroxyl radical. ABBS 1989; 5 : 235-40.

10. Dan N, Li XJ, Zhao BL, Zhang TM, Xin WJ. Scavenging effects of probimane on active oxygen free radicals by electron spin resonance. Acta Pharmacol Sin 1989; 10 :443-7

11. Beauchamp C, Fridovich I. Superoxide dismutase: Improved assays and an assay applicable to acrylamide gels. Anal Biochem 1971; 44 : 276-87.

12. Luo QQ, Sen MC, Gao W, Peng Q. A study on reaction kinetics of superoxide dimutase and its model compounds with superoxide ion by illumination. Chem J Chin Univ 1990; 11 : 928-32.

13. Gülçin I, Küfrevioğlu İ, Oktay M, Büyükokuroğlu ME. Antioxidant, antimicrobial, antiulcer and analgesic activities of nettle (Urtica diocia L.). J Ethnopharmacol 2004; 90 : 205-15.

14. Qu B, Huang D, Hampsch-Woodill M, Flanagan JA, Deemer EK. Analysis of antioxidant activities of common vegetables employing oxygen radical absorbance capacity (ORAC) and 
ferric reducing antioxidant power (FRAP) assays: a comparative study. J Agric Food Chem 2002; 50 : 3122-8.

15. Yıldız B. Cirsium Mill. In: Türkiye Bitkileri Listesi (Damarlı Bitkiler). Güner A, Aslan S, Ekim T, Vural M, Babaç MT, Gökyiğit N, editors. İstanbul: Botanik Bahçesi ve Flora Araştırmaları Derneği Yayını, 2012: 141-6.

16. Y1ldız B, Arabac1 T, Dirmenci T. Two new species of Cirsium (Asteraceae) and notes on allies from Turkey. Turk J Bot 2013; 37:1045-54.

17. Davis PH, Parris BS. Cirsium Mill. In: Flora of Turkey and the East Aegean Islands. Davis PH, editor. Edinburgh: Edinburgh University Press, 1975: 370-412.

18. Davis PH, Parris BS. Cirsium baytopae. Notes Roy Bot Gard Edinburgh. 1975

19. Zhishen J, Mengcheng T, Jianming W. The determination of flavonoid contents in mulberry and their scavenging effects on superoxide radicals. Food Chem 1999; 64:555-9.

20. Zou Y, Lu Y, Wei D. Antioxidant activity of Flavonoid-rich extract of Hypericum perforatum L in vitro. J Agric Food Chem 2004; 52: 5032-9.

21. Baskan KS, Tutem E, Ozer N. Spectrophotometric and Chromatographic Assessment of Contributions of Carotenoids and Chlorophylls to the Total Antioxidant Capacities of Plant Foods. J Agric Food Chem 2013; 61: 11371-81

22 Celik ES, Ozyurek M, Guclu K. Solvent effects on the antioxidant capacity of lipophilic and hydrophilic antioxidants measured by CUPRAC, ABTS/persulfate and FRAP methods. Talanta 2010; 81: 1300-9.

23. Cekic SD, Cetinkaya A, Avan AN, Apak R. Correlation of Total Antioxidant Capacity with Reactive Oxygen Species (ROS) Consumption Measured by Oxidative Conversion. J Agric Food Chem 2013; 61: 5260-70.

24. Khatoon M, Islam E, Islam R, Rahman AA, Alam AHMK, Khondkar P, Rashid M, Parvin S. Estimation of total phenol and in vitro antioxidant activity of Albizia procera leaves. BMC Res Notes 2013; 6:121-8.

25. Karasakal A, Gurkan YY. Determination of Ascorbic Acid in Common Fruits, Herbal Tea by Using Cuprac and Cerac Methods: A Kinetic Study. Asian J Chem 2012; 24: 2609-12.

26. Karaman Ş, Tütem E, Başkan KS, Apak R. Comparison of total antioxidant capacity and phenolic composition of some apple juices with combined HPLC-CUPRAC assay. Food Chem 2010; 120: 1201-9.

27. Vincenzo F, Verde V, Giacomino R, Ritieni A. Method for Measuring Antioxidant Activity and Its Application to Monitoring the Antioxidant Capacity of Wines. J Agric Food Chem 1999; 47:1035-9.
28. Abu Bakar MF, Mohamed M, Rahmat A, Fry J. Phytochemicals and antioxidant activity of different parts of bambangan (Mangifera pajang) and tarap (Artocarpus odoratissimus). Food Chem 2009; 113: 479-83.

29. NCCLS, (National Comittee for Clinical Laboratory Standards), Performance standards for antimicrobial disk susceptibility test. (6thed). Approved Standard, M2-A6, Wayne, PA. 1997.

30. Güllüce M, Sökmen M, Sahin F, Sökmen A, Adigüzel A, Özer H. Biological activities of the essential oil and methanolic extract of Micromeria fruticosa (L.) Druce ssp. Serpyllifolia (Bieb) PH Davis plants from the eastern Anatolia region of Turkey. J Sci Food Agric 2004; 84: 735-41.

31. Hogg S. Essential Microbiology. Chichester: John Wiley \& Sons, Ltd, 2005.

32. Nazaruk J. Antioxidant activity and total phenolic content in Cirsium five species from north-east region of Poland. Fitoterapia 2008;79:194-6.

33. Nazaruka J, Sylwia K. Czechowska RM , Borawska MH. Polyphenolic compounds and in vitro antimicrobial and antioxidant activity of aqueous extracts from leaves of some Cirsium species. Nat Prod Res 2008; 22: 1583-8.

34. Yin J,Heo Seong-Il, Wang MH. Antioxidant and antidiabetic activities of extracts from Cirsium japonicum roots. Korean Nutr Soc 2008; 2: 247-51.

35. Orhan Deliorman D, Ergun F, Yesilada E, Tsuchiya K, Takaishi Y, Kawazoe K. Antioxidant activity of two flavonol glycosides from Cirsium hypoleucum dc. through bioassayguided fractionation. Turkish J Pharm Sci 2007;4:1-14.

36. Altundag E, Ozturk M. Ethnomedicinal studies on the plant resources of East Anatolia of Turkey. Procedia Soc Behav Sci 2011; 19: 756-77.

37. Genç GE, Özhatay N. An ethnobotanical study in Çatalca (European Part of İstanbul) II. Turkish J Pharm Sci 2006; 3: 73-89.

38. Kızılarslan Ç, Özhatay N. An ethnobotanical study of the useful and edible plants of İzmit. Marmara Pharm J 2012; 16 : 134-40.

39. Yazıcıŏlu A, Tuzlacı E. Folk medicinal plants of Trabzon (Turkey). Fitoterapia 1996; 67 : 307- 18.

40. Sağıroğlu M, Arslantürk A, Akdemir ZK, Turna M. An ethnobotanical survey from Hayrat (Trabzon) and Kalkandere (Rize/Turkey). Biodivers Conserv 2012; 5: 31-43.

41. Akan H, Korkut MM, Balos MM. Arat Dağ1 ve Çevresinde (Birecik, Şanlıurfa) Etnobotanik Bir Araştırma. Fırat Unv Fen ve Muh Bil Dergisi 2008; 20 : 67-81.

42. Koçak S, Özhatay N. Wild Edible Plants Karaman (Southern Turkey). J Fac Pharm İstanbul 2013; 43 : 21-32. 